\title{
Analysis on Soy-Yamgurt Potential as Antidiabetic in Streptozotocin-Nicotinamide Induced Rats
}

\author{
Jessica Kwanariesta, Herla Rusmarilin, and Ismed Suhaidi \\ Department of Food Science and Technology, Faculty of Agriculture, Universitas Sumatera Utara, \\ Indonesia
}

\begin{abstract}
This study was conducted to determine the potential of soy-yamgurt probiotics drink from the mixture of yam and soy extract with a ratio of 1: 1 in reducing the fasting blood glucose level of rats induced by streptozotocin-nicotinamide. Based on the analysis of chemical and phytochemical characteristics of soy-yamgurt, it was found that it has water content $(80.97 \%)$, total solids $(18.85 \%)$, protein content $(11.95 \%)$, total lactic acid (1.03\%), viscosity (20.56 Pa.s), lactic acid bacteria $(10.22 \mathrm{log} \mathrm{CFU} / \mathrm{g})$, fiber content $(0.98 \%), \mathrm{IC}_{50}$ value $(44.99 \mu \mathrm{g} / \mathrm{ml})$, total phenol $(711.90 \mu \mathrm{gGAE} / \mathrm{g})$ and total flavonoids (1345.73 $\mu \mathrm{gQE} / \mathrm{g})$. The in vivo test used thirty 10-16 week old male Wistar rats with an average weight of 160-200 g divided into 5 groups: $\mathrm{P}_{1}$ (control), $\mathrm{P}_{2}$ (streptozotocinnicotinamide), $\mathrm{P}_{3}$ (glibenclamide of $0.45 \mathrm{mg} / \mathrm{kg}$ body weight), $\mathrm{P}_{4}$ ( $3 \mathrm{ml}$ of soy-yamgurt) and $\mathrm{P}_{5}$ (3.5 $\mathrm{ml}$ of soy-yamgurt).The results showed that the soy-yamgurt at the doses of 3 $\mathrm{ml} / 160 \mathrm{~g}$ body weight and $3.5 \mathrm{ml} / 160 \mathrm{~g}$ body weight for 4 weeks in streptozotocinnicotinamide-induced rats had significantly $(\mathrm{P}<0.01)$ lowered blood glucose levels and increased their weight.
\end{abstract}

Keywords: antioxidant activity, diabetes mellitus, soy milk, soy-yamgurt, streptozotocin nicotinamide

Received 24 February 2018 | Revised 28 March 2018 | Accepted 28 March 2018

\section{Introduction}

Diabetes mellitus (DM) has become one of the major health problems. The data from a global study show that the number of DM patients in 2011 has reached 366 million people, and is predicted to increase to 552 million by 2030. In 2006, more than 50 million people in Southeast Asia was recorded to suffer from DM. Based on the reports from the International Diabetes Federation (IDF) 183 million people are not aware of suffering from DM. The other research finding reports that $80 \%$ of people with DM live in low and middle income countries, and most of people with diabetes were 40 to 59 years old [1].

In overcoming DM problems, drugs serve only as a complement to the diet because it only needs to be given if the maximal diet formulation cannot control the blood sugar level. Oral

*Corresponding author at: Department of Food Science and Technology, Faculty of Agriculture, Universitas

Sumatera Utara, Jl. Prof A. Sofyan No. 3, Kampus USU, Medan 20155, Indonesia

E-mail address: kwanariesta@yahoo.com 
anti-diabetic drugs may be needed for people with diabetes who are allergic to insulin or who do not use insulin injections. Drug usage should be well controlled in order to have the right dose adjustment with its indication, without causing hypoglycemia. Over-consumption of antidiabetic drugs has undesirable side effects, so experts develop a safer anti-diabetic traditional treatment system.

Antioxidants are chemical compounds that can contribute one or more electrons to free radicals, so that the free radicals can be muted [2]. Based on the source of acquisition, antioxidants are divided into two: natural and artificial antioxidants (synthetic) [3]. The human body does not have antioxidant reserves in excess amount, so if there is excessive radical exposure then the body will require exogenous antioxidants. Due to the concerns about the possible unknown side effects of synthetic antioxidants, natural antioxidants are a much-needed alternative [4], [5]. Natural antioxidants are capable of protecting the body against damage caused by reactive oxygen species, inhibiting the occurrence of degenerative diseases and inhibiting lipid peroxide in food. Therefore, the research interest in natural antioxidants has been increasing in recent years [5].

Yam bean (Pachyrizus spp.) is a horticultural crop that has excellent potential to be developed because it has numerous benefits: (1) its tubers contain inulin that cannot be digested so that it can be used as a substitute for sugar, (2) its starch content can be used as a cosmetic ingredient, (3) it can be used as the basic ingredient of medicine for cancer, diabetes mellitus, abdominal pain and (4) it can be processed as food.

A survey done by Suzuki in 1998 showed that the low mortality from coronary heart disease, breast cancer, uterine cancer and atherosclerosis was influenced by high levels of soy-based foods consumption such as tofu, natto, miso and milk. Such low mortality is presumably due to the role of soy isoflavones, including genistein, daidzein and glycitein, which have biological activities as phytoestrogens and antioxidants [6].

It has been proved that the benefits of soy-yamgurt from yam bean extract containing watersoluble polysaccharide (WSP) known as inulin and soybean extract which contains many antioxidants, fiber and other nutrients can be increased by processing it into yogurt containing live lactic acid bacteria in digestion. This characteristic is very useful for people with diabetes or people who do low-calorie diet [7].

The existence of isoflavones and WSP, fibers, lactic acid bacteria add to the prestige of yam bean and soybean as the plants beneficial for health. Isoflavones can serve as antioxidants, so they are useful for preventing: (1) oxidative damage of cell membranes, (2) atherosclerosis due to oxidation of LDL (bad cholesterol), (3) coronary heart disease, (4) cardiovascular disease, and (5) oxidative damage of DNA. In addition, the antioxidant power of isoflavones is also useful to provide antiproliferative effects and inhibit the growth of melanoma cells (one of the 
triggers of cancer) [6], while WSP is useful for the health of flora living in the intestine such as Lactobacillus sp. [7].

Soy-yamgurt is a fermentation product of yam bean extract and soybean extract made by adding Lactobacillus bulgaricus bacteria and Streptococcus thermophillus bacteria. Soy-yamgurt is expected to maximize the utilization of soybean and yam bean as well as to increase its nutritional value. Soy-yamgurt is relatively more durable than fresh milk or powdered milk dissolved in water, but it must be stored in a cold place to maintain its quality for several days.

Yam bean extraxt contains flavonoids compounds, phenol compounds and other compounds that have antioxidant potency, so it can serve as an antidote to free radicals; however, its potential has never been explored. Therefore, a test for antioxidant activity of soy-yamgurt probiotics has been carried out and the results showed that soy-yamgurt probiotics have a strong $\mathrm{IC}_{50}$, just like those of vitamin $\mathrm{C}$ and synthetic BHT antioxidants.

\section{Materials and Method}

The materials used were tubers of yam bean of elephant varieties with 5 months of harvest age obtained from the plantation area in Tanah Seribu of Binjai, North Sumatra and soybean of Anjasmoro varieties obtained from traditional markets in Medan, North Sumatra. Several other materials were sugar (Gulaku), skim milk (Prolac), mineral water, arabic gum and Bio-kul yogurt starter bacteria (Streptococcus thermophilus, Lactobacillus bulgaricus, and Lactobacillus acidophilus). The reagents used in this research were MRSA (deMan Rogosa and Sharpe Agar), ethanol, aquadest, 96\% alcohol, DPPH (2.2-diphenyl-1-picrylhydrazyl), $\mathrm{NaOH}$ (sodium hydroxide), hexane solvent, concentrated $\mathrm{H}_{2} \mathrm{SO}_{4}$ (sulfuric acid), $\mathrm{NaCl}$ (sodium chloride), $\mathrm{C}_{6} \mathrm{H}_{12} \mathrm{O}_{6}$ (glucose), streptozotocin (Bioworld), nicotinamide, and buffer at $\mathrm{pH}$ 4.5. The animal experiments were 30 ten to sixteen week old white Wistar rats with 160 to $200 \mathrm{~g}$ weight.

The research was conducted in five stages. The first stage was making yogurt starter. The second stage was making yam bean extract. The third stage was making soybean extract. The fourth stage was making soy-yamgurt. The fifth stage was in-vivo testing on the rats with 4 parameters: weight weighing, hypoglycemic effect test, glucose tolerance, and in situ glucose absorption using inverted intestine using two factors of randomized factorial design (RFD). The first factor of the treatment was done through 5 levels of treatment: P1 = The control group was given aquadest for 31 days; $\mathrm{P} 2$ = The negative group was given nicotinamide of $230 \mathrm{mg} / \mathrm{kg}$ body weight and streptozotocin of $65 \mathrm{mg} / \mathrm{kg}$ body weight for 3 days, and was then given aquadest for 28 days; $\mathrm{P} 3$ = The positive group was given nicotinamide of $230 \mathrm{mg} / \mathrm{kg}$ body weight and streptozotocin of $65 \mathrm{mg} / \mathrm{kg}$ body weight for 3 days, and was then given glibenclamide of $0.45 \mathrm{mg} / \mathrm{kg}$ body weight for 28 days; $\mathrm{P} 4=$ The experimental group was given streptozotocin of $65 \mathrm{mg} / \mathrm{kg}$ body weight and nicotinamide of $230 \mathrm{mg} / \mathrm{kg}$ body weight for 3 days, 
and was than given soy-yamgurt of $3 \mathrm{ml} /$ head for 28 days; and P5 = The experimental group was given nicotinamide of $230 \mathrm{mg} / \mathrm{kg}$ body weight and streptozotocin of $65 \mathrm{mg} / \mathrm{kg}$ body weight for 3 days, and was then given soy-yamgurt of $3.5 \mathrm{ml} /$ head for 28 days. The second factor was the time of glucose level observation consisting of 4 stages: W1 (the $1^{\text {st }}$ week), W2 (the $2^{\text {nd }}$ week), W3 (the $3^{\text {rd }}$ week) and W4 (the $4^{\text {th }}$ week).

\subsection{Yoghurt Starter Making}

$16 \mathrm{~g}$ of skim milk powder added by $3 \%$ of sugar was dissolved with $100 \mathrm{ml}$ of hot water and then the temperature was lowered to $45{ }^{\circ} \mathrm{C}$. After that, the commercial yogurt starter culture (biocule plain) was added as much as $5 \%$ of the mixture volume and was stirred. Then the mixture was covered with polyethylene plastic and was perforated using a needle. Next, it was incubated at $40-45{ }^{\circ} \mathrm{C}$ for 6 hours. Pasasi was conducted 3 times. The resulting yogurt starter was stored in a refrigerator with a temperature of $4{ }^{\circ} \mathrm{C}$, on an anaerobic condition.

\subsection{Yam Bean Extract Making}

The tuber of yam bean was cleaned and put in a juicer. It was added by water with the ratio of yam bean and boiled water of 1:1. The result of juicing process was filtered using a filter cloth which has been blanched, and the extract was then taken out.

\subsection{Soy Milk Making}

The soybeans were sorted and soaked, then they were boiled twice (30 minutes for each), i.e. before and after the immersion of $0.2 \%$ of $\mathrm{NaHCO}_{3}$ (sodium bicarbonate) solution within 30 minutes. The soybean hull was then separated by squeezing and washing it with water many times for the easy process of hulling. The hull-less soybeans were given hot water $\left(100^{\circ} \mathrm{C}\right)$ with the ratio of soybeans to hot water of 1: 6 and then they were ground or blended. The soybean powder was filtered with a filtered cloth which has been blanched and the soy milk was left on a low heat for 20 minutes at a temperature of $80^{\circ} \mathrm{C}$.

\subsection{Soy-Yamgurt Making}

Soy-yamgurt was made from soy milk and yam bean extract with the ratio of 50\%:50\%, then it was added by skim milk powder (15\%) and sugar ( $2 \%)$, and was inoculated with the addition of starter $(3 \%)$ and mixed with the arabic gum $(0.6 \%)$. Furthermore, the incubation process was carried out by closing the mixture using perforated polyethylene plastic. The incubation was carried out at a temperature of $40 \pm 2^{\circ} \mathrm{C}$ for 6 hours. The soy-yamgurt that has been formed was stored in the refrigerator with a temperature of $4^{\circ} \mathrm{C}$, anaerobic conditions.

\subsection{In-Vivo Testing}

In-vivo bioassay was carried out to determine the potential of soy-yamgurt in lowering blood sugar levels in diabetic conditions. The tests for soy-yamgurt were performed as follows: 30 Wistar rats were put in a collective cage with room temperature of $20-25^{\circ} \mathrm{C}$. The rats were fed 
in ad libitum. All the rats were adapted for one week before the treatment was given. The experiment was carried out for 28 days, and the weight and blood sugar level of the rats were analyzed every week. The rats were divided into 5 groups: control, positive, negative, and experimental groups. Each group consisted of 6 rats.

Soy-yamgurt was given daily for 28 days in force feeding with a dose of $3 \mathrm{ml} / \mathrm{head}$ and $3.5 \mathrm{ml} /$ head. Streptozotocin induction was performed after 15 minutes of nicotinamide administration and was used to induce diabetes (hyperglycemia). Before the induction process, the rats had been given 1 week adaptation. Three days after the injection of streptozotocin, the rats' blood was taken through the tail and was measured with a glucometer to ensure that the rats were in hyperglycemic conditions. Before the blood was taken, the rats were fasted for 16 hours. Only were rats with fasting blood glucose levels of more than $126 \mathrm{mg} / \mathrm{dl}$ used. The analysis on the rats was realized in hypoglycemic effect testing [8], weight weighing, glucose tolerance [9] and in situ glucose absorption test with reversed intestine sac.

\section{Results and Discussion}

\subsection{Chemical Characteristics of Soy Milk and Soy-yamgurt}

Soybean is a commodity that has good source of nutrition, especially protein, because its amino acid structure almost resembles animal protein [10]. One of its processed products is soy milk. The chemical characteristics of soy milk can be seen in Table 1.

Table 1. Chemical Characteristics of Soy Milk

\begin{tabular}{cc}
\hline Parameters & Analysis Results \\
\hline Water content $(\% \mathrm{wb})$ & $89.1847 \pm 0.1048$ \\
Ash content $(\% \mathrm{db})$ & $0.3351 \pm 0.2478$ \\
Protein content $(\% \mathrm{db})$ & $4.4538 \pm 0.0067$ \\
Fat content $(\% \mathrm{db})$ & $2.2299 \pm 0.2076$ \\
Fiber content $(\% \mathrm{db})$ & $0.7763 \pm 0.0998$ \\
\hline
\end{tabular}

Notes: The test was done twice, the $( \pm)$ mark indicates standard deviation value

The test of soy-yamgurt included chemical and phytochemical characteristics based on the water content, total solids, protein content, total lactic acid, viscosity, lactic acid bacteria, fiber content, antioxidant activity, total phenolic, and total flavonoids. The chemical characteristics of soy-yamgurt can be seen in Table 2. 
Table 2. Chemical and Functional Characteristics of Soy-yamgurt

\begin{tabular}{cc}
\hline Parameters & Analysis Results \\
\hline Water content (\%) & $0.9777 \pm 0.1433$ \\
Total solids (\%) & $18.8527 \pm 0.2693$ \\
Protein content (\%) & $11.9495 \pm 0.9283$ \\
Total lactic acid (\%) & $1.0284 \pm 0.0250$ \\
Viscosity (pa.s) & $20.5656 \pm 2.2002$ \\
Lactic acid bacteria (log CFU/g) & $10.2216 \pm 0.0644$ \\
Fiber content (\%) & $0.9783 \pm 0.0124$ \\
\hline
\end{tabular}

Notes: The test was done twice, the $( \pm)$ mark indicates standard deviation value

\subsection{Phytochemical Characteristics of Yam Bean Extract, Soy Milk and Soy-yamgurt}

The results of testing the antioxidant activity $\left(\mathrm{IC}_{50}\right)$, total phenol and total flavonoids in yam bean extract, soy milk and soy-yamgurt can be seen in Table 3.

Table 3. Antioxidant Activity, Total Phenol and Total Flavonoids in Yam Bean Extract, Soy Milk, and Soy-Yamgurt

\begin{tabular}{cccc}
\hline Parameters & $\mathbf{I C}_{\mathbf{5 0}}(\boldsymbol{\mu g} / \mathbf{m l})$ & $\begin{array}{c}\text { Total Flavonoids } \\
(\boldsymbol{\mu g Q E} / \mathbf{g})\end{array}$ & $\begin{array}{c}\text { Total Fenol } \\
(\boldsymbol{\mu g G A E} / \mathbf{g})\end{array}$ \\
\hline Yam bean extract & 40.5379 & 892.4927 & 956.8532 \\
Soy milk & 41.6981 & $1,574.0026$ & 791.7033 \\
Soy-yamgurt & 44.9925 & $1,345.7266$ & 711.8978 \\
\hline
\end{tabular}

From the data analysis, it is found that the average $\mathrm{IC}_{50}$ values of yam bean extract, soy milk, and soy-yamgurt were $40.5379 \mu \mathrm{g} / \mathrm{ml}, 41.6981 \mu \mathrm{g} / \mathrm{ml}$ and $44.9925 \mu \mathrm{g} / \mathrm{ml}$, respectively. Based on the antioxidant activity strength table, yam bean extract, soy milk, and soy-yamgurt were among the strongest parameters because their $\mathrm{IC}_{50}$ values were below $50 \mathrm{ppm}$. The lower the value of $\mathrm{IC}_{50}$ was obtained the higher the antioxidant activity would be.

\subsection{In Vivo Test to Rat Experiments}

The result of the in vivo test that has been done on the rats showed that the treatment in each group of rats had highly significant different effect $(\mathrm{P}<0.01)$ on the hypoglycemic effect and had a significant effect $(\mathrm{P}<0.05)$ on the glucose absorption.

\subsection{Hypoglycemic Effect of Soy-yamgurt}

Blood glucose level is one of the parameters of diabetes condition. The type of treatment and periodic time of fasting blood glucose testing and their interactions had a highly significant different effect $(\mathrm{P}<0.01)$. Types of treatment gave a very significant different effect $(\mathrm{P}<0.01)$ on the percentage of the decrease of fasting blood glucose levels of the rats. 


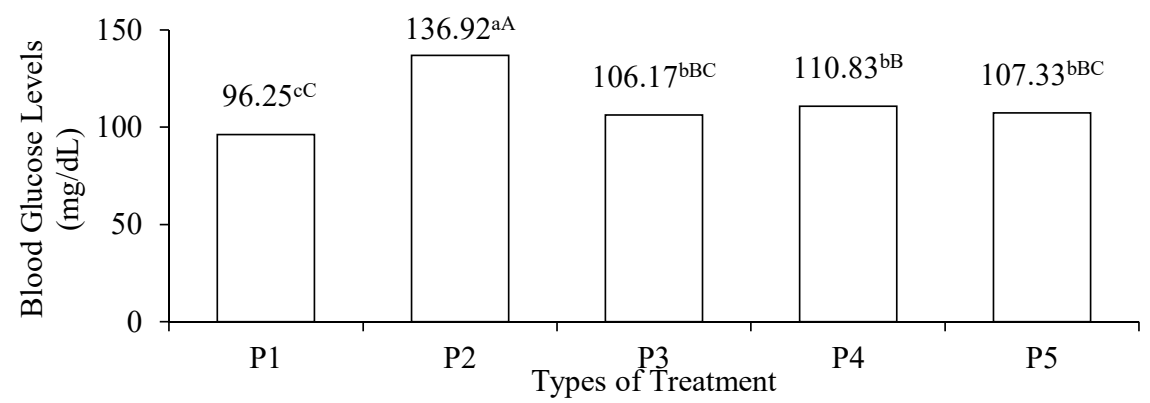

Notes: $\mathrm{P} 1=$ Control Group; $\mathrm{P} 2=$ Negative Group $(+$ streptozotocin-nicotinamide $) ; \mathrm{P} 3=$ Positive Group ( + streptozotocin-nicotinamide and glibenclamide); P4 = Experimental Group 1 (+ streptozotocin-nicotinamide and $3 \mathrm{ml}$ of soy-yamgurt); P5 = Experimental Group 2 (+ streptozotocin-nicotinamide and $3.5 \mathrm{ml}$ of soy-yamgurt)

Figure 1. Relation of Types of Treatment to Fasting Blood Glucose Level of Rats

Figure 1 shows that the effect of P2 treatment (negative group) had the highest fasting blood glucose level at $136.92 \mathrm{mg} / \mathrm{dL}$ and the lowest one was found in the effect of P1 treatment (control group) at $96.25 \mathrm{mg} / \mathrm{dL}$. In addition, Figure 1 also shows that after the 28 day test period, the rats in the $\mathrm{P} 2$ treatment (negative group) were still in diabetic condition, while in the P3 treatment (positive group), P4 treatment (experimental group treated with $3 \mathrm{ml}$ of soyyamgurt), and P5 (experimental group treated with $3.5 \mathrm{ml}$ of soy-yamgurt) the rats has returned to normal condition. The rats with P2 treatment (negative group) experienced a diabetic condition with fasting blood glucose levels at $136.92 \mathrm{mg} / \mathrm{dL}$ due to the induction of streptozotocin and the absence of alternative therapies that might cause damage to pancreatic $\beta$ cells and disruption to the insulin's work resulting in the increased levels of blood glucose in the rats. In this case, it has been proven that stz was able to cause diabetic condition to animal experiments. This finding is in line with the research done by Erwin [11] who found that streptozotocin can drive animals into a diabetic condition due to the formation of highly reactive free radicals that can cause damage to pancreatic $\beta$-cell membrane, protein, and DNA as they cannot produce insulin to convert glucose into glycogen.

Figure 1 shows the rats treated with P4 treatment and P5 treatment had fasting blood glucose levels close to the rats with P1 treatment (control group) and P3 treatment (positive group). Within 28 days, the fasting blood glucose levels of rats with P4 treatment (experimental group with $3 \mathrm{ml}$ of soy-yamgurt) returned to the normal condition at $110.83 \mathrm{mg} / \mathrm{dL}$ and in the P5 treatment (experimental group with $3.5 \mathrm{ml}$ of soy-yamgurt) the fasting blood glucose levels of rats also returned to the normal condition at $107.33 \mathrm{mg} / \mathrm{dL}$, with the restriction of fasting blood glucose levels of rats with diabetes at more than $126 \mathrm{mg} / \mathrm{dL}$.

The administration of soy-yamgurt in the experimental groups (P4 and P5) indicated that the performance of polysaccharides and antioxidants found in the soy-yamgurt was able to counteract free radicals and reduce oxidative stress resulting in the capability of lowering blood glucose levels. This finding is in line with the statement of Retnaningsih, et al. [12] that 
flavonoids can increase the activity of superoxide dismutase (SOD) antioxidants in rats so that it can reduce the destruction of pancreatic $\beta$-cells and the insulin performance is relatively good enough. Besides, the decreased blood glucose levels are increasingly obvious to a certain extent.

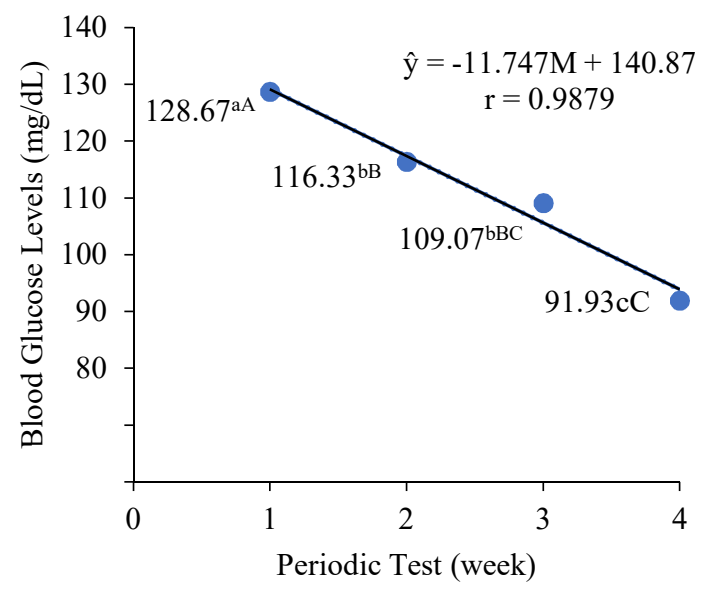

Figure 2. The Relationship of Periodic Test With Fasting Blood Glucose Levels in the Rat

ExperimentsThe average fasting blood glucose level of rats at the $1^{\text {st }}$ week was $128.67 \mathrm{mg} / \mathrm{dL}$ which was the highest fasting blood glucose level, and the longer the testing time was the lower the fasting blood glucose level would be. This was because streptozotocin-nicotinamide still worked at the $1^{\text {st }}$ week and $2^{\text {nd }}$ week. After the $3^{\text {rd }}$ week, the antioxidants in soy-yamgurt played their role in preventing free radicals and reducing oxidative stress so that they could lower the blood glucose levels. This finding is in line with the statement of Retnaningsih, et al. [12] that flavonoids can induce the activity of superoxide dismutase (SOD) antioxidants in rats so that it can reduce the damage of pancreatic $\beta$-cells resulting in the decrease of blood glucose levels.

The sharpest decrease in blood glucose levels was found in the P3 treatment (positive group), i.e. the induction of stz-na and the administration of $0.45 \mathrm{mg} / \mathrm{kg}$ bb of glibenclamide. The sharp decrease was also experienced by the rats in P4 and P5 (experimental group), i.e. the induction of sth-na and the administration of $3 \mathrm{ml}$ and $3.5 \mathrm{ml}$ of soy-yamgurt.

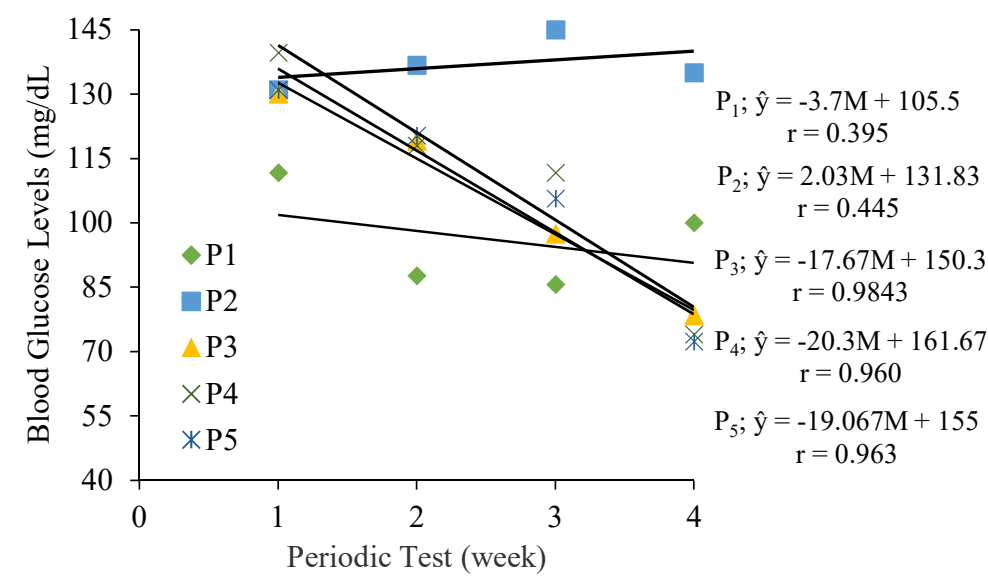

Figure 3. Relationship of Types of Treatment and Periodic Test Against Fasting Blood Glucose Levels of Rats 
Figure 3 shows that the blood glucose levels of hyperglycaemic rats on P4 treatment and P5 treatment returned to the normal condition $(<126 \mathrm{mg} / \mathrm{dL})$ after the administration of soyyamgurt for 28 days. The administration of soy-yamgurt in the experimental group of P4 and P5 indicated the performance of antioxidants in soy-yamgurt that could counteract free radicals and functioned as the inhibitors of $\alpha$-glucosidase enzymes that could lower blood glucose levels. This finding is in accordance with the statement of Havsteen [13] that the function of flavonoids is to inhibit the activity of the $\alpha$-glucosidase enzyme thus delaying glucose uptake and potentially lowering blood sugar levels. The $\alpha$-glucosidase enzyme inhibitor is a potential agent used for DM therapy. The inhibition of $\alpha$-glucosidase enzyme activity might work in inhibiting polysaccharide breakdown in the small intestine so that the absorbable monosaccharide was reduced and, at the same time, the increase in the post-prandial blood glucose levels of diabetics could be inhibited [14].

Table 4. Effect of Types of Treatment on the Percentage of the Change of rat Blood Glucose Level Within 28 Days

\begin{tabular}{cccc}
\hline \multirow{2}{*}{ Group } & \multicolumn{2}{c}{ Blood glucose levels $(\mathbf{m g} / \mathbf{d L})$} & $\begin{array}{c}\text { Percentage of blood } \\
\text { glucose level changes }(\%)\end{array}$ \\
\cline { 2 - 3 } & Initial & Final & $19.3893 \pm 2.5539$ \\
$\mathrm{P}_{1}$ & $124.0000 \pm 2.6458$ & $100.0000 \pm 5.1962$ & $-3.3139 \pm 4.6336$ \\
$\mathrm{P}_{2}$ & $130.6667 \pm 1.1547$ & $135.0000 \pm 6.2450$ & $38.7874 \pm 2.8539$ \\
$\mathrm{P}_{3}$ & $128.0000 \pm 1.0000$ & $78.3333 \pm 3.0551$ & $44.3878 \pm 2.5296$ \\
$\mathrm{P}_{4}$ & $133.0000 \pm 4.3589$ & $74.0000 \pm 5.0000$ & $49.5505 \pm 2.2443$ \\
$\mathrm{P}_{5}$ & $143.6667 \pm 11.2398$ & $72.3333 \pm 3.2146$ & \\
\hline
\end{tabular}

Notes: The test was administered three times, the $( \pm)$ mark indicates the standard deviation value; $(+)=$ decreased blood glucose levels; $(-)=$ increased blood glucose levels; $\mathrm{P}_{1}=$ Control Group; $\mathrm{P}_{2}=$ Negative Group $\left(+\right.$ streptozotocin-nicotinamide); $\mathrm{P}_{3}=$ Positive Group $(+$ streptozotocin-nicotinamide and glibenclamide); $\mathrm{P}_{4}=$ Experimental Group 1 ( + streptozotocinnicotinamide and $3 \mathrm{ml}$ of soy-yamgurt); $\mathrm{P}_{5}=$ Experimental Group 2 (+ streptozotocinnicotinamide and $3.5 \mathrm{ml}$ of soy-yamgurt)

Table 4 shows that the administration of $3 \mathrm{ml}$ or $3.5 \mathrm{ml}$ of soy-yamgurt had the effect of lowering blood sugar levels. The administration of $3.5 \mathrm{ml}$ of soy-yamgurt had a greater percentage of decrease in fasting blood glucose levels when compared with a dose of $3 \mathrm{ml}$. This was because the higher the dose was administered the higher the number of oligosaccharides and antioxidant activities that worked in preventing free radicals would increase. In addition, the difference in the percentage of decrease in blood glucose levels was assumed to be caused by the amount of the intake of oligosaccharides into the gastrointestinal tract, so that the higher the doses were administered the more amount of intake of oligosaccharides would come in [15].

Figure 4 shows that after 28 days, the P2 group of rats (negative group) experiences an increase to the above normal blood glucose levels, indicated by a negative percentage; meanwhile, the P3 group (positive group), P4 group and P5 group experienced a decrease in blood glucose levels characterized by a positive percentage. 


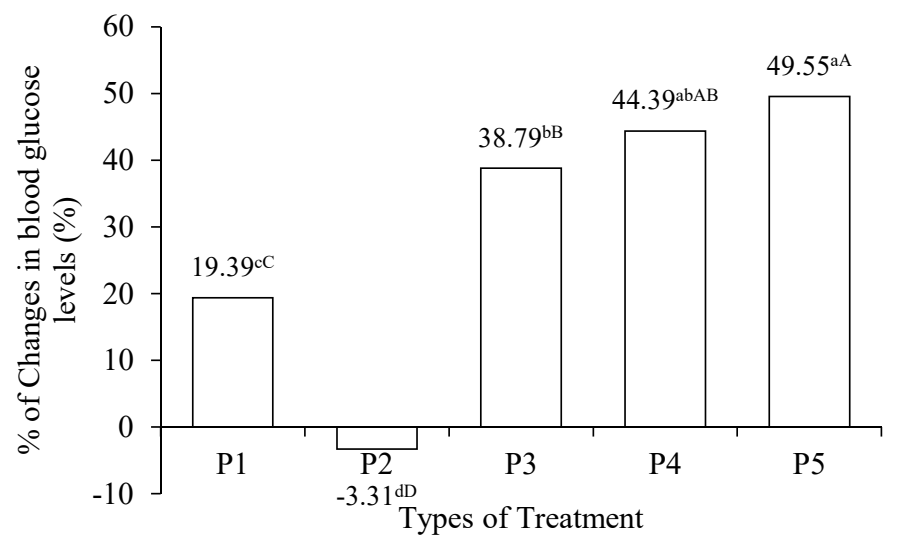

Figure 4. Relationship of Effect of the Types of Treatment to the Percentage of Changes in the Fasting Blood Glucose Level of Rats (mg/dL) Within 28 Days

The rats with P2 treatment experienced an increase in blood glucose levels due to the absent administration of alternative therapies and were given only regular food so that the stz administered caused the increase in blood glucose levels presumably due to damage to pancreatic $\beta$-cells leading to disruption in the way the insulin worked.

Figure 4 shows that the rats in the experimental groups (P4 and P5) experienced decreased blood glucose levels, i.e. $44.39 \%$ and $49.55 \%$, respectively. After being treated for 28 days, the experimental group experienced a decrease in blood glucose levels caused by the activity of antioxidant compounds and oligosaccharides in soy-yamgurt that had hypoglycemic effects. This finding is consistent with Rudrappa [16] stating that inulin cannot be directly broken down into sugars, inulase enzyme is needed for the solution, which will then be fermented in the intestines. In the soybeans are isoflavones compounds which are phytoestrogens acting as the antioxidants that can inhibit the oxidation of glucose [17]. Water-soluble fiber can delay and reduce blood glucose levels by increasing food transit times in the small intestine, delaying gastric emptying and slowing down glucose absorption [18].

\subsection{The In Situ Glucose Absorption Test Uses an Inverted Intestine Sac}

The types of treatment and the effect of the test time had highly significant effect $(\mathrm{P}<0.01)$ on glucose level in the rats' inverted intestine test, while the interaction between the two had no significant effect $(\mathrm{P}>0.05)$. 


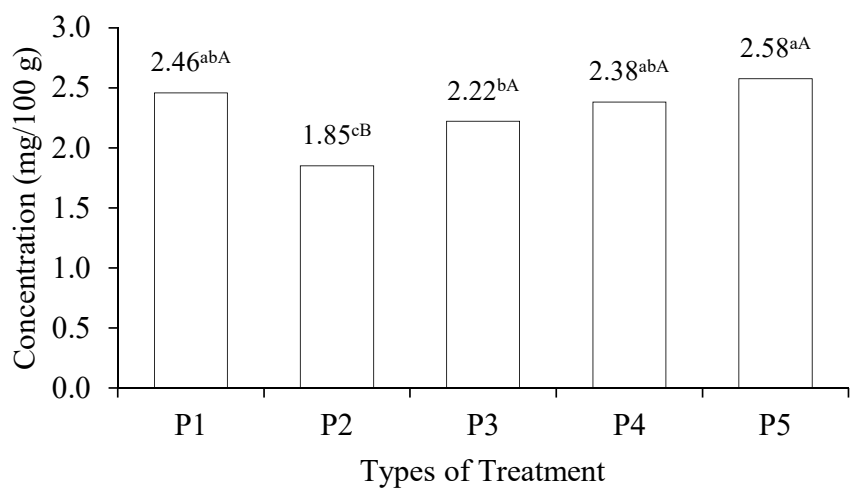

Notes: $\mathrm{P}_{1}=$ Control Group; $\mathrm{P}_{2}=$ Negative Group ( + streptozotocin-nicotinamide); $\mathrm{P}_{3}=$ Positive Group (+ streptozotocin-nicotinamide and glibenclamide); $\mathrm{P}_{4}=$ Experimental Group 1 streptozotocin-nicotinamide and $3 \mathrm{ml}$ of soy-yamgurt); $\mathrm{P}_{5}=$ Experimental Group 2 (+ streptozotocin-nicotinamide and $3.5 \mathrm{ml}$ of soy-yamgurt)

Figure 5. Relationship of the Types of Treatment to the Absorption of Glucose in Inverted Intestine of Rats

Figure 5 shows that the experimental group of P4 and P5 had glucose levels approaching the P1 treatment (control group) while the P2 treatment (negative group) had low glucose level. This indicated that the intestines of the negative group of rats (positive for diabetes) had digested almost all of the $20 \%$ glucose solution administered; meanwhile, in the P4 and P5 experimental groups, $10 \%$ of soy-yamgurt administration was relatively higher than P2. This was because the WSP in soy-yamgurt had been degraded into short chain fatty acids by microbes in the intestine with the help of enzymes. Short-chain fatty acids produced might inhibit blood glucose because WSP with a unique chemical structure could not be digested by digestive enzymes.

According to the literature of Ministry of Health of the Republic of Indonesia [14], the activity of $\alpha$-glucosidase enzymes such as maltase and sucrose in hydrolyzing oligosaccharides to glucose, fructose and other monosaccharides in the small intestinal wall can be inhibited by the $\alpha$-glucosidase inhibitor compound, one of which is flavonoids. The inhibition of this enzyme activity is effective in reducing the digestion of carbohydrate and its absorbs process in the small intestine so as to decrease the post prandial blood sugar level of diabetes mellitus. This medicinal compound affects only a decrease in blood sugar levels at mealtimes and does not affect blood sugar levels thereafter. The $\alpha$-glucosidase inhibitor may also inhibit the activity of the $\alpha$-amylase enzyme in the hydrolysis of polysaccharides in the intestinal lumen. 


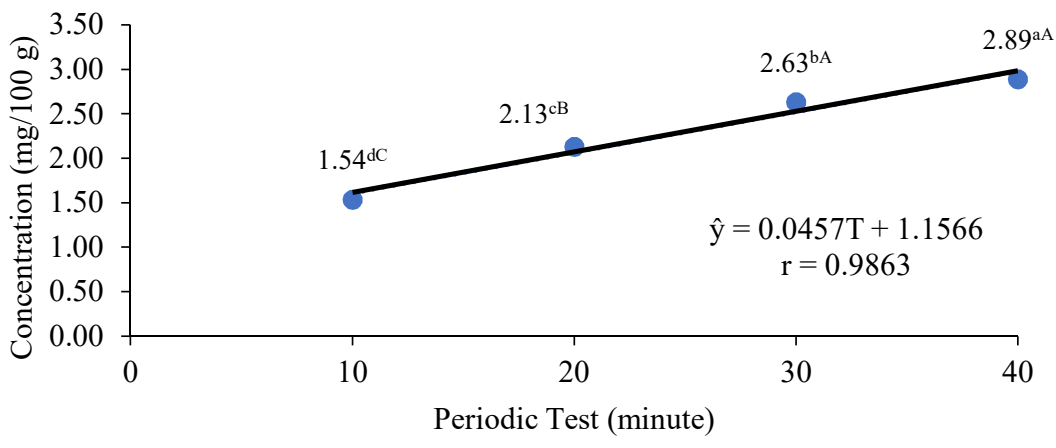

Figure 6. Relationship of Periodic Test With the Absorption of Glucose in the Inverted Intestine of Rats

Figure 6 shows that the $T_{1}$ treatment (10 minutes) had a glucose level of at least $1.54 \mathrm{mg} / 100 \mathrm{~g}$ of the ingredients, and the $\mathrm{T}_{4}$ treatment (40 minutes) had the highest glucose level at 2.89 $\mathrm{mg} / 100 \mathrm{~g}$ of the material. This suggests that, at the $10^{\text {th }}$ minute test, all of the $20 \%$ of glucose solution administered could be absorbed because the administered soy-yamgurt had not reacted and had not been degraded by the microbes in the intestine. The longer test duration made the absorption of glucose in the intestine inhibited because hydrolyzing oligosaccharides in soyyamgurt has been inhibited by $\alpha$-glucosidase inhibitor compounds.

\section{Conclusion}

The experimental group (P5), i.e. the nicotinamide induction of $230 \mathrm{mg} / \mathrm{kg}$ body weight, streptozotocin of $65 \mathrm{mg} / \mathrm{kg}$ of body weight and $3.5 \mathrm{ml}$ of soy-yamgurt were the rats experiencing the most significantly decreased blood glucose level $(\mathrm{P}<0.01)$ compared to other treatment groups. The administration of $3.5 \mathrm{ml}$ of soy-yamgurt could significantly $(\mathrm{P}<0.01)$ lower the blood glucose levels after 4 weeks (28 days) in the streptozotocin-nicotinamide induced rats.

The mechanism of lowering blood glucose levels by water-soluble polysaccharides (WSP) was related to the nature of the WSP for its capability of forming a gel in the digestion that could slow stomach emptying, accelerate transit time in the small intestine, control glucose absorption in the blood and serve as a prebiotic to decrease the blood glucose levels.

$10 \%$ of soy-yamgurt was able to inhibit the absorption of glucose in the small intestine of the rats in the experimental group, while the small intestine of the rats in the negative group could not inhibit the glucose administered. This was because the oligosaccharides found in soyyamgurt could form gel and could be degraded into short chain fatty acids by microbes with the help of enzymes. The short-chain fatty acids produced could inhibit blood glucose so that less absorption occurred. 


\section{REFERENCES}

[1] K. S. Trisnawati and S. Setyorogo, "Faktor risiko kejadian diabetes melitus tipe 2 di puskesmas Kecamatan Cengkareng Jakarta Barat tahun 2012," Jurnal Ilmiah Kesehatan, vol. 5, no. 1, pp. 6-11, 2013.

[2] E. Suhartono, Fujiati and I. Aflanie, "Oxygen toxicity by radiation and effect of Glutamic Piruvat Transamine (GPT) activity rat plasma after vitamine C treatment," Presented at Internatinal Seminar on Environmental Chemistry and Toxicology, Yogyakarta, 2002.

[3] S. Dalimartha and M. Soedibyo, Awet Muda dengan Tumbuhan Obat dan Diet Suplemen. Jakarta: Trubus Agriwidya, 1999.

[4] D. Rohdiana, "Aktivitas daya tangkap radikal polifenol dalam daun the," Majalah Jurnal Indonesia, vol. 12, no. 1, pp. 53-58, 2001.

[5] T. Sunarni, "Aktivitas antioksidan penangkap radikal bebas beberapa kecambah dari biji tanaman familia papilionaceae," Jurnal Farmasi Indonesia, vol. 2, no. 2, pp.53-61, 2005.

[6] M. Astawan, "Departemen Teknologi Pangan dan Gizi IPB," July 5, 2009. [Online] Available: http://www.masenchipz.com/bahaya-laten-sosis.

[7] L. Lingga, Cerdas Memilih Sayuran. Jakarta: Agromedia Pustaka, 2010.

[8] A. M. M. Ruzaidi et al., "Protective effect of polyphenol-rich extract prepared from Malaysian cocoa (Theobroma cacao) on glucose levels and lipid profiles in streptozotocininduced diabetic rats," Science of Food and Agriculture, vol. 88, no. 8, pp. 1441-1447, 2008.

[9] J.T. Xie, J. A. Wu, S. Mehendale, H. H. Aung, and C. S. Yuan, "Anti-hyperglycemic effect of the polysaccharides fraction from American ginseng berry extract in ob/ob mice," Phytomedicine, vol. 11, no. 2-3, pp. 182-187, 2004.

[10] F. G. Winarno, Pangan, Gizi, Teknologi dan Konsumen. Jakarta: Gramedia Pustaka Utama, 1993.

[11] Erwin, Etriwati, and Rusli, "Mencit (Mus musculus) galur balb-c yang diinduksikan streptozotocin berulang sebagai hewan model diabetes melitus," Jurnal Kedokteran Hewan, vol. 6, no. 1, pp. 47-50, 2012.

[12] C. Retnaningsih, Darmono, B. Widianarko, and S. F. Muis, "Peningkatan aktivitas antioksidan superoksida dismutase pada tikus hiperglikemi dengan asupan tempe koro benguk (Mucuna pruriens L.)," Agritech, vol. 33, no. 2, pp. 154-161, 2013.

[13] B. H. Havsteen, "The biochemistry and medical significance of the flavonoids," Pharmacology \& Therapeutics, vol. 96, no. 2-3, pp. 67-202, 2002.

[14] Indonesia Ministry of Health, Pharmaceutical care untuk penyakit diabetes melitus. Jakarta: Ministry of Health, 2005.

[15] T. S. A. Candra, E. N. Dewi, and R. Ibrahim, "Pengaruh pemberian ekstrak gracilaria verrucose terhadap kadar glukosa darah tikus putih (rattus norvegicus)," Jurnal Saintek Perikanan, vol. 8, no. 1, pp. 1-6, 2012.

[16] U. Rudrappa, "Jicama (Yam bean) Nutrition Fact," 2009. [Online] Available: http://nutrition-and-you.com. [Acesessed 17 April 2017]

[17] M. T. Velasquez and S. J. Bhathena, "Role of dietary soy protein in obesit," International Journal of Medical Science, vol. 4, no. 2, pp. 72-82, 2007.

[18] L. Anderson and J. W. Walter, Compositional changes in trypsin inhibitors, phytics acid, saponins, and isoflavones related to soybean processing. overview of soybean processing and products. American Institute of Nutrition, 1995. 